Anticipated changes include, but are not limited to:

- Adding 336, 337, 338 fields

- Spelling out non-transcribed abbreviations in 255, 300, 500, 504 and other fields

- Converting Latin abbreviations to English equivalents in 245, 260, and other fields

- Converting dissertation notes in 502 field to multiple subfields

- Removing GMDs (after 31 March 2016)

- Heading changes in accordance with RDA

Heading changes are anticipated to spell out abbreviations in headings like "Dept." and to change Bible and Koran headings in accordance with RDA practice.

\title{
TRAINING PRESENTATIONS, WEBCASTS, AND WEBINARS
}

Georgia Public Library Cataloging Summit

Originally convened August 9-11, 2011. The documents are available from the Library of Congress' training website. http://www.loc.gov/aba/rda/Georgia training_aug_2011.html

Library of Congress

Catalogers Learning Workshop. Includes free webinars and course materials for training provided by the Library of Congress.

http://www.loc.gov/catworkshop/

Library of Congress

RDA Training Materials

http://www.loc.gov/catworkshop/RDA\%20training\%20materials/LC\%20RDA\%20Training/LC\%20RDA\%20 course\%20table.html

\section{SELECTED ARTICLES FROM CURRENT LIBRARY JOURNALS}

Barton, Joshua, and Lucas Mak. "Old Hopes, New Possibilities: Next-Generation Catalogues and the Centralization of Access." Library Trends 61, no. 1 (Summer 2012): 83-106.

Butler, Rebecca. "The Rise and Fall of Union Classification." Theological Librarianship: An Online Journal of the American Theological Library Association 6, no. 1 (4 December 2012). https://journal.atla.com/ojs/index.php/ theolib/article/view/254 (accessed January 28, 2013).

Chang, Hsia-Ching, and Hemalata Iyer. "Trends in Twitter Hashtag Applications: Design Features for Value-Added Dimensions to Future Library Catalogues." Library Trends 61, no. 1 (Summer 2012): 248-258.

Croissant, Charles R. "FRBR and RDA: What They Are and How They May Affect the Future of Libraries." Theological Librarianship: An Online Journal of the American Theological Library Association 5, no. 2 (10 June 2012). https://journal.atla.com/ojs/index.php/theolib/article/view/234 (accessed January 28, 2013).

Debus-López, Karl E., Diane Barber, Caroline Saccucci, and Camilla Williams. "The Electronic Cataloging in Publication Cataloging Partnership Program: A Model for Cooperative Cataloging for the Twenty-First Century.” In "Cataloging Collaborations and Partnerships," ed. Rebecca L. Mugridge. Special issue, Cataloging \& Classification Quarterly 51, no. 1/3 (2013): 25-54.

El-Sherbini, Magda. “Bibliotheca Alexandrina’s Model for Arabic Name Authority Control.” Library Resources \& Technical Services 57, no. 1 (2013): 4-17. 
Fairclough, Ian. "Collaborative Initiatives in Error Handling and Bibliographic Maintenance: Use of Electronic Distribution Lists and Related Resources." In "Cataloging Collaborations and Partnerships," ed. Rebecca L. Mugridge. Special issue, Cataloging \& Classification Quarterly 51, no. 1/3 (2013): 265-290.

Falk, Patricia K., Elizabeth Hertenstein, and Stefanie Dennis Hunker. "Catalogers Unite! Creating Documentation through Collaboration." In "Cataloging Collaborations and Partnerships," ed. Rebecca L. Mugridge. Special issue, Cataloging \& Classification Quarterly 51, no. 1/3 (2013): 214-223.

Gallaway, Teri Oaks, and Mary Finnan Hines. "Competitive Usability and the Catalogue: A Process for Justification and Selection of a Next-Generation Catalogue or Web-Scale Discovery System.” Library Trends 61, no. 1 (Summer 2012): 173-185.

Han, Myung-Ja. “New Discovery Services and Library Bibliographic Control.” Library Trends 61, no. 1 (Summer 2012): 162-172.

Ilik, Violeta.. “Off-Site Storage from a Cataloging Point of View.” Serials Librarian 63, no. 3/4 (Oct-Dec 2012): 350-358.

Julien, Charles-Antoine, Catherine Guastavino, and France Bouthillier. "Capitalizing on Information Organization and Information Visualization for a New-Generation Catalogue.” Library Trends 61, no. 1 (Summer 2012): 149-161.

Lee, Seungmin, Taewoo Nam, and Youngjoon Nam. "Revising Cataloging Rules and Standards to Meet the Needs of People with Disabilities: A Proposal for South Korea.” Library Resources \& Technical Services 57, no. 1 (2013): 18-29.

Lisius, Peter H. "PCC Practice for Assigning Uniform Titles for Motion Pictures: Principle versus Practice." Cataloging \& Classification Quarterly 50, no. 8 (2012): 869-893.

Liu, Maggie, Lolita Kwok, and Kylie Chan. "Why Change to the Chinese Classification Scheme? A Case Study in an Academic Library." Cataloging \& Classification Quarterly 50, no. 8 (2012): 852-868.

Loesch, Martha Fallahay. "RDA in Perspective: How to Use the Library Literature to Your Advantage.” Technical Services Quarterly 30, no. 1 (2013): 1-14.

Lynema, Emily, Cory Lown, and David Woodbury. "Virtual Browse: Designing User-Oriented Services for Discovery of Related Resources." Library Trends 61, no. 1 (Summer 2012): 218-233.

MacEwan, Andrew, Anila Angjeli, and Janifer Gatenby. "The International Standard Name Identifier (ISNI): The Evolving Future of Name Authority Control." In "Cataloging Collaborations and Partnerships," ed. Rebecca L. Mugridge. Special issue, Cataloging \& Classification Quarterly 51, no. 1/3 (2013): 55-71.

Majors, Rice. “Comparative User Experiences of Next-Generation Catalogue Interfaces.” Library Trends 61, no. 1 (Summer 2012): 186-207.

McGurr, Melanie, Catherine Mason, and Michael Monaco. "Public and Academic Library Cataloging Collaboration in Ohio's NACO Funnel Project.” In "Cataloging Collaborations and Partnerships,” ed. Rebecca L. Mugridge. Special issue, Cataloging \& Classification Quarterly 51, no. 1/3 (2013): 72-81.

Miksa, Francis. "The Legacy of the Library Catalogue for the Present.” Library Trends 61, no. 1 (Summer 2012): 7-34. 
Mitchell, Erik. “Is RDA Ready?: An Analysis of Case Studies on RDA Testing.” Technical Services Quarterly 30, no.1 (2013): 70-82.

Panchyshyn, Roman S. "Asking the Right Questions: An E-Resource Checklist for Documenting Cataloging Decisions for Batch Cataloging Projects.” Technical Services Quarterly 30, no. 1 (2013): 15-37.

Pirmann, Carrie. "Tags in the Catalogue: Insights From a Usability Study of LibraryThing for Libraries.” Library Trends 61, no. 1 (Summer 2012): 234-247.

Prebor, Gila, and Nachum Zitter. "Classification and Indexing in Yeshiva Libraries: Analysis of the Systems, Their Sources and Development.” Cataloging \& Classification Quarterly 50, no. 8 (2012): 830-851.

Schultz-Jones, Barbara, Karen Snow, Shawne Miksa, and Richard L. Hasenyager, Jr. "Historical and Current Implications of Cataloguing Quality for Next-Generation Catalogues.” Library Trends 61, no. 1 (Summer 2012): 49-82.

Schwing, Theda, Sevim McCutcheon, and Margaret Beecher Maurer. "Uniqueness Matters: Author-Supplied Keywords and LCSH in the Library Catalog." Cataloging \& Classification Quarterly 50, no. 8 (2012): 903-928.

Skinner, Debra G. "A Comparison of Searching Functionality of a VuFind Catalogue Implementation and the Traditional Catalogue." Library Trends 61, no. 1 (Summer 2012): 208-217.

Smiraglia, Richard P., and Hur-Li Lee. "Rethinking the Authorship Principle." Library Trends 61, no. 1 (Summer 2012): 35-48.

Spiteri, Louise F., and Laurel Tarulli. "Social Discovery Systems in Public Libraries: If We Build Them, Will They Come?” Library Trends 61, no. 1 (Summer 2012): 132-147.

Taniguchi, Shoichi. "Viewing RDA from FRBR and FRAD: Does RDA Represent a Different Conceptual Model?" Cataloging \& Classification Quarterly 50, no. 8 (2012): 929-943.

Tarulli, Laurel, and Louise F. Spiteri. "Library Catalogues of the Future: A Social Space and Collaborative Tool?” Library Trends 61, no. 1 (Summer 2012): 107-131.

Theimer, Sarah. “A Cataloger's Resolution to Become More Creative: How and Why." Cataloging \& Classification Quarterly 50, no. 8 (2012): 894-902.

Young, Janis L., and Yael Mandelstam. "It Takes a Village: Developing Library of Congress Genre/Form Terms.” In "Cataloging Collaborations and Partnerships," ed. Rebecca L. Mugridge. Special issue, Cataloging \& Classification Quarterly 51, no. 1/3 (2013): 6-24.

Submitted by Lynn Berg, Librarian for Technical Services

New Brunswick Theological Seminary (NJ) 